\title{
AZ ÉLELMISZERPAZARLÁS ÉS A FOGYASZTÓI TUDATOSSÁG KAPCSOLATA
}

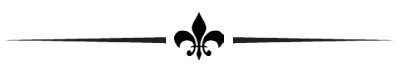

\section{CONNECTION OF FOOD WASTE AND CONSUMER AWARENESS}

\author{
- \\ SZÚCS, RÓBERT SÁNDOR

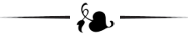 \\ Neumann János Egyetem, Kereskedelem, Marketing és Nemzetközi Gazdálkodási Tanszék \\ (John von Neumann University, Commerce, Marketing and International Business Department) \\ H-500o Szolnok, Tiszaligeti sétány 14. \\ e-mail: szucsrobertsandor@gmail.com
}

\begin{abstract}
7 One of the most significant problems of developed countries is the food waste and the efficient consumption of food. The developed countries struggle with the overweight and obesity while the other part of the world fight with the starvation. Nowadays, the number of overweight people exceeds the number of hungry people. The consumer asserts that his decisions are consistent and rational. In my research (size of the sample is 918 people) I have to distinguish between the real and presumed awareness in case of food consumption. Real awareness is rooted in the knowledge and behavior of consumer which manifest in a low level of waste, while the presumed awareness exists only in the consumer belief in himself. According to my results, the food waste is significant in Hungary and the proportion of waste is related to the consumer's income. I can state that the presumed awareness is stronger than the real awareness.
\end{abstract}

KuLCSSZAVAK: élelmiszerpazarlás, fogyasztói tudatosság, háztartás

JEL-KóDoK (JEL CODES): I30, M31, Q18

DOI: https://doi.org/10.20494/TM/6/1/5

\section{BEVEZETÉS - INTRODUCTION}

Az ellenétetek vonzzák egymást, tartja a mondás. Napjaink fogyasztói társadalma ezt a mondást sokszorosan képes igazolni; sőt mi több, ezek az ellentétek egyszerre, egymás mellett élnek. Egyszerre és tömeges mértékben van jelen a gazdagság és a szegénység, a takarékoskodás igénye és a pazarlás, a túlsúlyosság és az éhezés, a tudatosság igénye és az emocionális döntések garmadája, hogy csak néhány példát említsünk.

Globálisan vizsgálva az elhízottság és túlsúlyosság alakulását, a WHO 2016-os adatai szerint 1,9 milliárd 18 év fölötti túlsúlyos ember
KEYWORDs: food waste, consumer awareness, household

él a Földön. Közülük 650 millióan tartoznak az elhízottak közé. Ez azt jelenti, hogy a felnőttkorú lakosság 39\%-a túlsúlyosak csoportjába sorolható, míg 13\%-uk elhízott. Mára a Föld lakosságának többsége olyan országban él, ahol a túlsúlyosság és elhízottság több embert halálát okozza, mint az alultápláltság (WHO, 2018). Az Európai Lakossági Egészségfelmérés 2014. évi adatai szerint a túlsúlyosak és elhízottak közé tartozik a felnőtt korú lakosság több mint fele (54\%). A tanulmány adatai szerint a 18-34 éves férfiak 39,3\%-a, a 35-64 évesek 71,1\%-a, a 65 évnél idősebbek 72,1\%-a sorolható a túlsúlyos vagy elhízott kategóriák valamelyikébe. A nők esetében ezek az arányszámok sorrend- 
ben $23,4 \%, 52,8 \%$, illetve $65 \%$ (KSH, 2015). A legfejlettebb országokat tömörítő szervezet, az OECD 2015-ös adatai szerint a férfiak 72\%-a, míg a nők $64 \%$-a sorolható a túlsúlyos vagy elhízott kategóriák valamelyikébe. Különösen súlyos a helyzet hazánkban, ahol 2014-ben az átlagos túlsúlyossági ráta $62,3 \%$ volt a felnőtt korú lakosság körében. A nők 31,5\%-a, míg a férfiak 28,2\%-a volt elhízott. Ez a gyakorlatban azt jelenti, hogy a magyarországi adatok a negyedik legrosszabbak a világon, az Egyesült Államok, Új-Zéland, Mexikó mögött mi következünk a rangsorban; vagyis Magyarország a leginkább elhízott európai ország (OECD, 2017). A számok egyértelmúen és jól tükrözik azt, hogy a fejlett országok komoly egészségügyi problémával néznek szembe az elhízottság és túlsúlyosság formájában. A mérleg másik serpenyőjében ugyanakkor ott van az a tény, hogy 2017-ben 821 millió ember éhezett a Földön. Számuk az utóbbi három évben emelkedett és visszatért a 10 évvel ezelőtti szintre. A trend figyelmeztető és sürgős jelzést küld, hogy többet kell tennünk, ha el akarjuk érni 2030-ra a Fenntartható Fejlődési Célok éhezésre vonatkozó pontját (Sustainable Development Goal of Zero Hunger), nevezetesen felszámoljuk az éhezés minden formáját 2030-ra (FAO, 2018). 821 millió ember éhezik a Földön, miközben a világ 26 leggazdagabb embere 2018-ban öszszesen 1,4 trillió dollárt keresett. Ez az összeg megegyezik a legszegényebb 3,8 milliárd ember keresetének összegével (LUHBY, 2019). Ez szemléletesen azt jelenti, hogy a 26 leggazdagabb ember annyi pénzt keresett 2018-ban, mint a Föld lakosságának a szegényebb fele.

\section{VALÓdi ÉS VÉLT TUDATOSSÁG AZ ÉLELMISZEREK FOGYASZTÁ- SÁNAK TERÜLETÉN - REAL AND} Presumed AWARENESS IN THE AREA of Food CONSUMPTION

Korábbi kutatásaim (SZƯCS, 2019) felhívták a figyelmet a valós (tényleges és pontos tudással alátámasztható) tudatosság és a vélt (a fogyasztó fejében élő, saját magáról alkotott idealizált kép) fogyasztói tudatosság közötti jelentős különbségre. Megállapítást nyert, hogy a fogyasz- tó kognitív tudásszintje meglehetősen alacsony a fogyasztói tudatosság témakörében, ugyanakkor az affektív komponens meglehetősen erős, a fogyasztói érzelmek által erősen vezérelt. A kutatások azt mutatták, hogy a fogyasztó valódi tudása, így a tényleges tudatosság szintje meglehetősen gyenge (kutatási területtől függően a fogyasztóknak csupán 10-20\%-a mutatott fel elfogadható szintû, valódi tudással alátámasztható tudatosságot), ennek ellenére meglehetősen tudatos fogyasztói magatartást tulajdonítanak a fogyasztók saját maguknak. A fogyasztók többsége erős énvédelmi mechanizmust mutat fel, vagyis a fogyasztói tudatosság kognitív és affektív komponensei nincsenek összhangban. A gondolatmenet, az ellentétek sokasága az élelmiszerek előállítására és felhasználására is kiterjeszthető. Az élelmiszerek tudatos felhasználásáról képzelt fogyasztói magatartásunk egy utópisztikus vízió, melyben annak tudatos felhasználásunkról álmodozunk. Az adatok azonban nem igazolják ezt a vélelmezett tudatosságot. A KSH 2019. februári adatai szerint nemzetgazdasági szinten Magyarországon 2018. januárja és decembere között a bruttó átlagkereset $329900 \mathrm{Ft}$ volt (KSH, 2019). Kiszámolva, ez nettó 219384 Ftnak felelt meg. Szintén a KSH 2018. novemberi adatai szerint a háztartások egy före jutó havi fogyasztási kiadásainak szerkezetét vizsgálva, azok legjelentősebb tétele - nem meglepő módon - az élelmiszerek és alkoholmentes italok kategóriája. Erre havonta átlagosan 24573 Ftot költöttek a magyar háztartások a 2018. év 1. félévében. A háztartások egy főre jutó havi kiadásainak megoszlását vizsgálva az élelmiszerek és alkoholmentes italok 27,7\%-os súlyt képviselnek. Ez az érték a 2017. év azonos időszakához képest 0,9\%-pontos emelkedést mutat (KSH, 2018a).

A mérleg másik vége itt is jelen van. A hazai átlagbérek utóbbi időben tapasztalt jelentős emelkedése ellenére is azt mondhatjuk, hogy a hazai átlagbér nemzetközi összehasonlításban még mindig meglehetősen alacsonynak nevezhető, amiből következően a diszkrecionális jövedelemszint szintén alacsony. Ettől komolyabb probléma, hogy az EUROSTAT 2016-os adatai szerint a depriváltak (anyagilag súlyos nehézségekkel küzdők) aránya 32\% hazánkban. Az EU átlagos értéke 16\%. Magyarország 
a listán Romániát, Bulgáriát és Görögországot megelőzve, de még így is negyedik legroszszabb helyen áll (EUROSTAT, 2017). A KSH módszertani eltérésből adódóan elnézőbb a szegénységet illetően. A jövedelmi szegénységi arány 13,4-ról 12,8\%-ra, míg a súlyos anyagi depriváció aránya 14,5\%-ról 10,2\%-ra csökkent 2016-ról 2017-re hazánkban (KSH, 2018b). Akár az EUROSTAT, akár a KSH adatait veszszük alapul, hazai nettó kereseteket és az élelmiszerekre elköltött pénzösszeget vizsgálva kézenfekvő és racionális megoldásnak tűnik az élelmiszerek tudatos felhasználása. A takarékoskodás kiváló formája lehet a legnagyobb költségtényező hatékony felhasználására való törekvés, nevezetesen élelmiszerek tudatos felhasználása. A valóság azonban egészen más képet mutat, nem csupán hazánkban, hanem a fejlett társadalmak egészének körében.

Az Európai Bizottság 2016. márciusában publikált 2012-re becsült adatai szerint az élelmiszerhulladék mértéke az EU-28-ban 88 millió tonna. Ez azt jelenti, hogy az EU-28ban az egy személyre jutó élelmiszer-hulladék évente $173 \mathrm{~kg} /$ fót jelent. Az EU-ban a 2011-ben termelt élelmiszerek összmennyisége $865 \mathrm{~kg}$ / fő volt, ami azt jelenti, hogy összességében a megtermelt élelmiszer 20\%-át elpazaroljuk. $\mathrm{Az}$ elpazarolt élelmiszer 53\%-ért, azaz $47 \pm 4$ millió tonnáért a háztartások felelősek. Ez egy före vetítve $92 \pm 9 \mathrm{~kg}$-ot jelent. A termelés $11 \%$ os, a feldolgozás 19\%-os, az éttermek 12\%-os, míg a nagy- és kiskereskedelem 5\%-os arányban jelennek meg az élelmiszer-pazarlásban. A naturáliában kifejezett számoknak természetesen komoly anyagi vonzata is van. Az élelmiszerpazarlással összefüggő költségek összegét 143 milliárd euróra becsülik. A költségek kétharmada, azaz mintegy 98 milliárd euró a háztartások élelmiszerpazarlásával hozható öszszefüggése (STENMARCK et al., 2016). A vélhetően jelzôt mindenképpen fontos megemlíteni, ugyanis DEÁK (2017), illetve STENMARCK és munkatársai (2016) is kifejti tanulmányukban, hogy pontos adatok nem állnak rendelkezésünkre ilyen téren. Szükséges megjegyezni, hogy ez sajnálatos módon nem csupán hazánkra, hanem az EU más országaira is igaz, „az adatok nem léteznek vagy hiányosak” (lásd: STENMARCK et al. (2016:63-649)) mondattal találkozhatunk folyamatosan. SZABÓ-BÓDI
(2018) BIOIS 2011-es tanulmányára hivatkozva leírja, hogy az egyes EU-s országok pazarlásának szintjében jelentős eltérés tapasztalható, melynek mértéke az Egyesült Királyságban 137 kg/fö/év, Luxemburgban 133 kg/fő/év, Hollandiában 113 kg/fó/év. Átlagosnak tekinthető e tekintetben Dánia ( $91 \mathrm{~kg} /$ fó/év), Belgium ( $89 \mathrm{~kg} \mathrm{kg/fo//év)} \mathrm{és} \mathrm{Írország} \mathrm{(69} \mathrm{kg/fö/év)} \mathrm{is.} \mathrm{A}$ becslés alapján az átlagnál kevesebb élelmiszerhulladékot termelnek a spanyolok (49 kg/fö/ év); a finnek ( $41 \mathrm{~kg} /$ fö/év) és hazánk fogyasztói is (39 kg/fő/év). SZABÓ-BÓDI és munkatársai (2018) ugyanakkor azt is kifejtik, hogy a leírt $39 \mathrm{~kg} /$ fö/év élelmiszerhulladék érték nem reális, az közvetett becsléssel került meghatározásra, ettől kutatásaik magasabb 68 kg/fő/ év értéket tartanak reálisnak. Egy bizonyos, az értékeket nézve komoly számháború zajlik, egészen nagy kilengéseket mutatva, a vizsgálatok csak most kezdődnek igazán. A pazarlás mérése természetesen nem egyszerü folyamat, hibáktól terhelt (NAEEM et al., 2006), komoly és munkaigényes feladatot jelent, számos háztartást kellene rábírni arra, hogy a feleslegról pontos naplót vezessen, ráadásul hosszabb időszakon keresztül. HUBERT és SZÚCS (2017) publikációjukban ábrázolják az élelmiszerszemét keletkezésének hatástérképét, mely a fenti gondolatkörökkel szoros összefüggést mutat.

A FAO 2011-es adatai szerint a globális helyzet még ennél is rosszabb, az emberi fogyasztásra szánt élelmiszereknek mintegy harmadát, a 2009-es adatok szerint 32\%-át, elveszítjük vagy elpazaroljuk, ami nagyságrendileg 1,3 milliárd tonnát jelent (WORLD RESOURCE INSTITUTE, 2013). A pazarlás 35\%-a fogyasztók számlájára írható. A számítási metódusuk alapján egy átlagos európai és észak-amerikai fogyasztó 95-115 kg élelmiszert pazarol évente, míg Dél-Afrikában és Dél-Délkelet-Ázsiában ez az érték csupán 6-11 kg/fő/év. Jól látható, hogy fejlett országok sokkal több élelmiszert pazarolnak, mint a fejlődő országok. DEÁK Ferenc a Földművelésügyi Minisztérium Élelmiszerlánc-felügyeleti Főosztály főosztályvezető-helyettesének 2017-ben tartott, több forrást szintetizáló (BIOIS, 2011; NÉBIH, 2016) előadására hivatkozva azt mondhatjuk, hogy a Magyarországon keletkező élelmiszerhulladék pontos mennyiségéről jelenleg még csupán becsléseink vannak. A becsült mennyiség hoz- 
závetőlegesen 1,8 millió tonnát jelent évente, vagyis egy átlagos magyar család a becslések alapján évente kb. 50 ooo forint értékü élelmiszert dob ki (DEÁK, 2017). A hazai tradicionális családi mintában megtalálhatók az élelmiszerek tudatos felhasználásra nevelő szülői intelmek. Számtalanszor hallhattuk a tanítást, hogy „Az étel nem játék!”, de a „Nem vesszük meg, van otthon, először azt edd meg!”, „Nem dobáljuk ki, mások éheznek!” mondatok sem ismeretlenek. Az affektív komponens jelen van, a kérdés az, hogy ez hogyan befolyásolja a konatív, vagyis magatartási komponenst. A korábban közölt adatok szerint a kettő között jelentős eltérés tapasztalható. A pazarlás káros hatásainak kezelésére több megoldás is létezik, melyek teljeskörű bemutatása jelen tanulmánynak nem célja. Csupán egyet kiragadva, a teljesség igénye nélkül, a káros hatásokat mérsékelve az elmúlt néhány évben a Magyar Élelmiszerbank Egyesület az Európai Élelmiszerbankok Szövetségének tagjaként egyre fokozódó figyelmet kapva foglalkozik az élelmiszerpazarlás visszaszorításával, a felesleg felhasználásával, azok rászorulókhoz történő eljuttatásával. A kezdeményezés egyértelmúen nem oldja meg a pazarlás globális problémáját („csepp a tengerben”), azonban a rászorulók számára ez a kis segítség életmentő lehet, úgy, hogy mindez jelentős anyagi ráfordítást, erőfeszítést nem igényel a felajánlók részéről, csupán egy kis odafigyelést, törődést. Az Egyesület a képződött felesleget, felajánlásokat az üzleti és magán szektortól is várja.

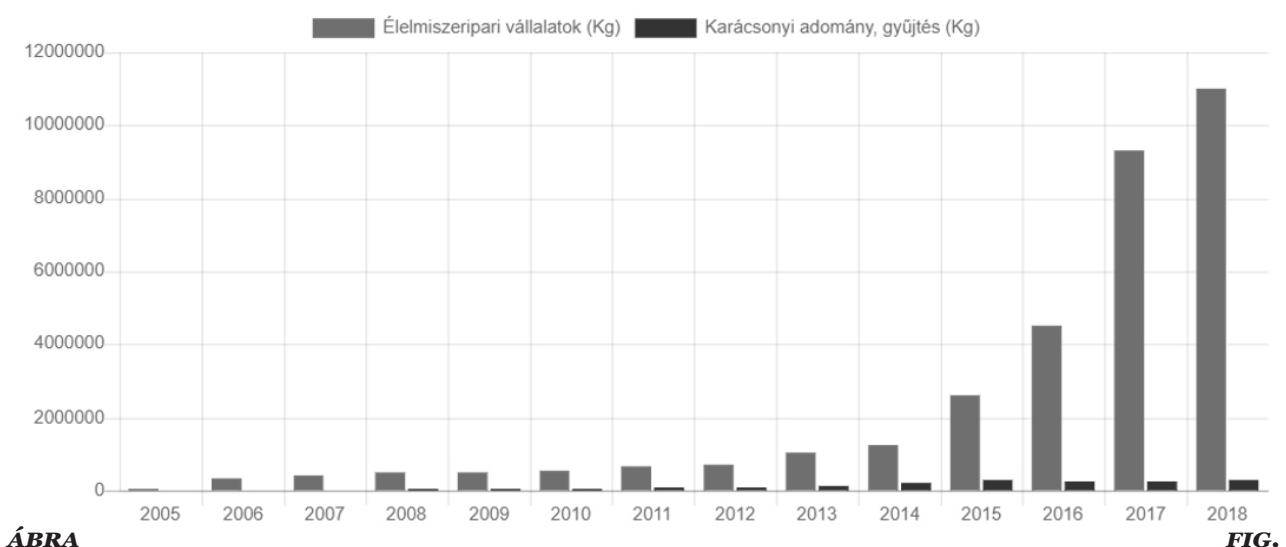

1. ÁBRA

A Magyar Élelmiszerbank Egyesület által gyújtött élelmiszer mennyisége

(Quantity of Collected Food by Hungarian Food Bank Association)

Forrás (Source): Magyar Élelmiszerbank Egyesület, 2018

Megjegyzés (Notes): gray area: food companies ( $\mathrm{kg}$ ), black area: Christmas donation, collection $(\mathrm{kg})$

A kezdeményezés az áldozatos munka, a kiemelt média figyelem hatására komoly növekedési potenciált mutat fel, melyet az 1 . ábra szemléltet. Az Élelmiszerbank Egyesület 2018-ban 350 partnerszervezetén keresztül több mint 300 ooo embernek juttatott el ingyenesen több mint 11 ooo tonna élelmiszeradományt Magyarországon, összesen több mint 6,5 milliárd forint értékben, mely magában foglalja Karácsonyi gyüjtésünk (284 tonna) eredményét is.

Jelen kutatómunkám célja annak megállapítása, hogy vajon a hazai fogyasztók hogyan látják élelmiszer felhasználásuk alakulását, mennyire ismerik el a pazarlás tényét, hogyan látják annak mértékét, mennyire érvényesül a korábban is említett erős énvédő mechanizmus az élelmiszerpazarlás témakörében. Szükséges megjegyeznem, hogy jelent tanulmánynak nem célja - számos okból következően, úgymint a kutatási keretösszeg, a terjedelmi korlátok stb. - a teljességre törekvés, így számos globálisan fontos megoldási lehetőség nem kerül megemlítésre, úgymint a keletkezett felesleg komposztálása, annak energetikai hasznosítása, stb. Jelen tanulmány sokkal inkább a mikro-, az egyén vagy család szintjére fókuszál, sem mint a makro-, a globális megoldások keresésének lehetőségeire. 


\section{ANYAg ÉS MÓDSZERTAN -}

\section{MATERIAL AND METHODS}

A tudatos élelmiszerfelhasználással, élelmiszerpazarlással kapcsolatos attitűdök vizsgálata kapcsán kérdőíves kutatást folytattam le 918 fős fogyasztói minta bevonásával, egyetemi hallgatók segítségével. Az egyetemi hallgatók a papír alapú kérdőívek kitöltetésének formájában segédkeztek a minél nagyobb reprezentativitásra való törekvés kikötése mellett, melyet korlátozott az a tény, hogy a megkérdezettek a kérdezóbiztosok tágabb ismerősi köréből származtak. A minta kiválasztásánál ezen túl a véletlenszerüség dominált. A megkérdezettek a válaszok megadásához külső segítséget nem kaptak, a kérdezőbiztosok nem segítették munkájukat. A kutatási költségkeret (mindenféle anyagi forrást teljes egészében nélkülöző kutatásról beszélünk) sajnálatos módon nem tette lehetővé a reprezentatív mintavételt és a kvalitatív kutatások lefolytatását, azonban a minta nagy elemszámából következően az táptalajul szolgálhat más, jobb anyagi forrásokat felvonultató kutatásoknak, példának okán a sikeres részek felhasználása révén. A felmérés 15 megyére terjedt ki. A mintában a legnagyobb arányban a Jász-Nagykun-Szolnok megyei kitöltők voltak (39,1\%), de Pest megye (24,5\%), Bács-Kiskun megye (20,0\%), Békés megye (5,9\%), Csongrád megye $(5,2 \%)$ lakosai is képviseltették magukat. A falusi kitöltők aránya $20,2 \%$, a városi kitöltőké $56,3 \%$, a megyeszékhelyen élók 17,6\%-ban, a fóvárosiak 5,9\%-ban voltak jelen a mintában. A megkérdezettek 68,9\%-a átlagosnak ítélte családja anyagi helyzetét. Az átlag alatti jövedelmet jelölők kumulatív aránya $10,9 \%(2,3 \%$ jelentősen átlag alatti, 8,6\% kis mértékben átlag alatti bevallott jövedelemmel), míg az átlag feletti jövedelmet bevallók kumulatív aránya 20,2\% (17,1\% kis mértékben átlag feletti, 3,1\% jelentősen átlag feletti jövedelemmel). A kérdőíveket olyan személyek töltötték ki, akik az adott háztartásban/ családban jellegzetesen az élelmiszerek beszerzését végzik. A kitöltésre 2018. november 20. és 2018. december 10. között volt lehetőség. A mintában a 14-18 éves korosztálytól a 70 év fölöttiekkel bezárólag, minden korcsoportból voltak kitöltők. A minta átlagos életkora: $42,2 \pm 14,0$ év. A legnagyobb súllyal megjele- nő életkori csoportok a 19-24 éves korosztály (13,6\%), a 40-44 éves korosztály (16,0\%), a 45-49 éves korosztály (13,0\%) és az 50-54 éves korosztály $(10,9 \%)$ voltak. A mintában a nők aránya $64,9 \%$, a férfiak aránya $35,1 \%$. Az érettségivel rendelkezők aránya a legmagasabb a mintában (46,2\%), majd óket követi a felsőfokú végzettséggel rendelkezők aránya $(29,6 \%)$, szakmunkás végzettséggel a megkérdezettek 18,2\%-a, míg általános iskolai végzettséggel a megkérdezettek 6\%-a rendelkezett. A kérdőív a családban élő felnőttkorú és gyermekkorú személyek számára is kitért, mint esetleges befolyásoló tényezőre.

\section{KUTATÁSI EREDMÉNYEK - RESULTS}

Kiinduló pontként fontos annak vizsgálata, hogy a megkérdezettek hogyan ítélik meg saját tudatosságuk szintjét. A megkérdezettek saját maguk tudatossági szintjét egy 3,9-es átlagos értékkel jellemezték 5-fokozatú Likert-skálán, ahol az 5-ös érték jelentette a tudatosság legmagasabb szintjét. Ezzel szemben a megkérdezettek saját háztartásuk tudatossági szintjét már csak 3,58-as értékkel jellemezték. A vélelmezett tudatossági fok átlagát a megkérdezettek neme, életkora, lakóhelyének típusa jelentős mértékben nem befolyásolja. A számított Cramer-féle asszociációs vizsgálatok igazolták a kapcsolat alacsony szintjét. A szekunder adatokhoz hasonlóan a jövedelem hatása nem csak makrogazdasági szinten fejt ki hatást a tudatosságra, hanem a legkisebb egység, a család szintjén is. A jelentősen átlag alatti jövedelemmel rendelkezők tudatosságukat 4,1-es értékkel jellemezték, míg a jelentősen átlag feletti jövedelemmel rendelkezők már csak 3,46os értékkel jellemezték saját tudatosságukat; vagyis az alacsonyabb jövedelem, valószínüsíthetően kényszerből, magasabb odafigyelést, megfontoltságot vár el a fogyasztótól, ezzel együtt a tudatosság szintje emelkedik. Jelen kutatás eredményeképpen kialakuló vélelmezett tudatossági szint jól illeszkedik a korábbi kutatási eredményekhez, ahogyan az is, hogy a fogyasztó énvédő mechanizmusának következtében saját személyét felülértékeli másokkal szemben, jelen esetben még a vele azonos ház- 
tartásban élő személyek tudatossági szintjével szemben is.

Kutatómunkám során igyekeztem olyan élelmiszereket összeválogatni, amelyet a háztartások zömében fogyasztanak, lehetőség szerint jelentős mennyiségben. A vizsgálatba termékkör a mintavétel okán nem lehet teljes (zöldségek, tojás, zsiradékok stb.), ugyanis a termékkör túlzott bővítése a kitöltési kedvet drasztikus visszavetette volna (a kitöltók nem kaptak anyagi ellentételezést a munkájukért). A megkérdezetteket kértem, hogy az egyes élelmiszerekból becsüljék meg, hogy milyen mértékü élelmiszerpazarlást feltételeznek. A részletes adatokat az 1. táblázat tartalmazza.

1. TÁBLÁZAT

Élelmiszerpazarlás aránya a fogyasztók véleménye szerint

TABLE 1 (Proportion of Food Waste According to the Opinion of Consumers)

\begin{tabular}{|c|c|c|c|c|c|c|c|c|c|c|c|c|}
\hline & $\begin{array}{c}\text { Nem } \\
\text { fogyasz- } \\
\text { tunk } \\
\text { (don't } \\
\text { eat) }\end{array}$ & o\% & $\begin{array}{l}1- \\
5 \%\end{array}$ & $\begin{array}{c}6- \\
10 \%\end{array}$ & $\begin{array}{c}11 \\
-15 \%\end{array}$ & $\begin{array}{c}16 \\
-20 \%\end{array}$ & $\begin{array}{c}21 \\
-25 \%\end{array}$ & $\begin{array}{l}26- \\
30 \%\end{array}$ & $\begin{array}{l}26- \\
30 \%\end{array}$ & $\begin{array}{l}36- \\
40 \%\end{array}$ & $40 \%-$ & $\begin{array}{l}\text { Átlag } \\
\text { (avg) }\end{array}$ \\
\hline $\begin{array}{l}\text { Kenyér } \\
\text { (Bread) }\end{array}$ & 3,1 & 30,3 & 27,1 & 15,6 & 5,5 & 5,7 & 3,2 & 2,7 & 2,2 & 1,3 & 3,4 & 7,9 \\
\hline $\begin{array}{l}\text { Kifli, zsömle } \\
\text { (Croissant, } \\
\text { bun) }\end{array}$ & 6,6 & 51,8 & 19,8 & 9,4 & 3,0 & 2,4 & 1,4 & 1,3 & 0,9 & 1,1 & 2,3 & 4,7 \\
\hline $\begin{array}{l}\text { Édes pékáru } \\
\text { (Sweet } \\
\text { bakery) }\end{array}$ & 10,3 & 63,6 & 13,9 & 3,3 & 2,6 & 1,7 & 0,7 & 1,3 & 0,3 & 0,5 & 1,7 & 3,1 \\
\hline $\begin{array}{l}\text { Sós pékáru } \\
\text { (Salty bakery) }\end{array}$ & 8,2 & 65,1 & 15,3 & 3,9 & 1,6 & 1,4 & 0,5 & 1,2 & 0,4 & 0,5 & 1,7 & 2,9 \\
\hline $\begin{array}{l}\text { Tej } \\
\text { (Milk) }\end{array}$ & 4,4 & 70,3 & 13,2 & 4,4 & 1,6 & 1,3 & 1,5 & 1,0 & 0,4 & 0,5 & 1,3 & 2,7 \\
\hline $\begin{array}{l}\text { Joghurt } \\
\text { (Yoghurt) }\end{array}$ & 7,2 & 73,8 & 9,5 & 2,8 & 1,7 & 0,5 & 1,1 & 0,8 & 0,7 & 0,7 & 1,2 & 2,4 \\
\hline $\begin{array}{l}\text { Sajt } \\
\text { (Cheese) }\end{array}$ & 1,3 & 79,7 & 10,9 & 2,5 & 1,6 & 0,7 & 0,9 & 0,7 & 0,3 & 0,4 & 1,0 & 1,9 \\
\hline $\begin{array}{l}\text { Túró rudi/ } \\
\text { tejszelet } \\
\text { (Túró rudi / } \\
\text { milk slice) }\end{array}$ & 11,0 & 78,3 & 4,9 & 2,0 & 0,7 & 0,4 & 0,7 & 0,3 & 0,3 & 0,4 & 1,0 & 1,5 \\
\hline $\begin{array}{l}\text { Felvágott } \\
\text { (Cold cuts) }\end{array}$ & 5,0 & 51,3 & 24,2 & 7,4 & 4,2 & 3,0 & 1,2 & 0,8 & 0,7 & 0,8 & 1,5 & 4,0 \\
\hline $\begin{array}{l}\text { Gyümölcs } \\
\text { (Fruit) }\end{array}$ & 0,5 & 60,7 & 21,8 & 6,8 & 3,4 & 2,2 & 1,1 & 0,7 & 0,3 & 0,5 & 2,0 & 3,4 \\
\hline $\begin{array}{l}\text { Otthon fött } \\
\text { étel } \\
\text { (Home cooked } \\
\text { food) }\end{array}$ & 0,3 & 42,3 & 31,5 & 10,6 & 3,7 & 4,0 & 2,3 & 1,6 & 0,7 & 0,3 & 2,6 & 5,2 \\
\hline
\end{tabular}

Forrás (Source): Saját kutatás, 2019 (Own research, 2019)

Fenti táblázat adatai alapján jól látható, hogy a megkérdezettek szerint a legnagyobb átlagos pazarlási aránnyal a kenyér (7,9\%), az otthon fótt étel $(5,2 \%)$, a kifli/zsömle $(4,7 \%)$, illetve a felvágottak kategóriája (4,0\%) jelenik meg. Az Európai Unió legfrissebb adatait ala- pul véve megállapíthatjuk, hogy a háztartások a szekunder adatokhoz képest alábecsülik a pazarlás mértékét. Az élelmiszerek felhasználása területén is igaz a tétel, miszerint a tudatosságot felül-, míg a pazarlás mértékét alábecsülik a fogyasztók, vagyis a vélt és valós tudatosság 
közötti jelentős különbség az élelmiszerek felhasználásának területén is megfigyelhető. $\mathrm{Az}$ adatokat szürve az átlagostól alacsonyabb bevallott jövedelemszinttel rendelkezőkre azt tapasztalhatjuk, hogy a pazarlás becsült mértéke a kenyér esetében 6,3\%-ra, a kifli/zsömle termékkategóriában 4,2\%-ra, az otthon fött ételekre 4,4\%-ra csökken. Az átlagostól magasabb bevallott jövedelemszinttel rendelkezők esetén a becsült pazarlás mértéke emelkedik, a kenyér esetében 10,0\%-ra, a kifli/zsömle termékkategóriában 7,0\%-ra, az otthon fótt ételek esetében 6,0\%-ra emelkedik, de a gyümölcsök esetében is eléri az 5,0\%-ot. Jól látható és a szekunder adatokkal összecsengő eredményeket figyelhetünk meg; a jövedelemszint emelkedésével a tudatos felhasználás csökken, a pazarlás mértéke emelkedik. Megfigyelhető még az pazarlási adatok vizsgálata során a gyermekszám befolyásoló hatása is, bár nem egyértelműen és nem erősen. Ennek oka vélelmezhető módon a növekvő családnagyságban, a fogyasztással összefüggő bizonytalanságban ke- resendő. Az 1 gyermekkel rendelkezők esetén a kenyér pazarlási arányszáma 8,1\%-ra, a zsömle esetében 5,0\%-ra, az otthon fött ételek esetén 6,5\%-ra emelkedik. 2 és ennél több gyermekszám esetén a fenti kategóriákban 9,0\%, 6,0\%, 5,5\%-os arányszámokkal találkozunk. A magasabb értékü termékek esetén (tej, joghurt, túró rudi, stb.) a különbség nem jelentős, sőt, az átlaghoz mérten gyakran alacsonyabb értékekkel találkozunk.

„Nincs kedvünk már megenni a kétnapos zsömlét, az összenyomott túróstáskát, a megbarnult banánról nem is beszélve. Hát kidobjuk. Veszünk frisset. Ezzel azonban utat nyitunk a pazarlásnak...” (F. SZABÓ, 2017). Kutatási eredményeim a fogyasztók saját megítélése alapján számszerüsítik a fent nevezett jelenség mértékét. Az alábbi 2. ábra szemlélteti a felsorolt állításokkal szembeni egyetértés átlagos szintjét egy 5-fokozatú Likert-skálán, ahol az 5-ös érték jelentette az állítással szembeni teljes egyetértést.

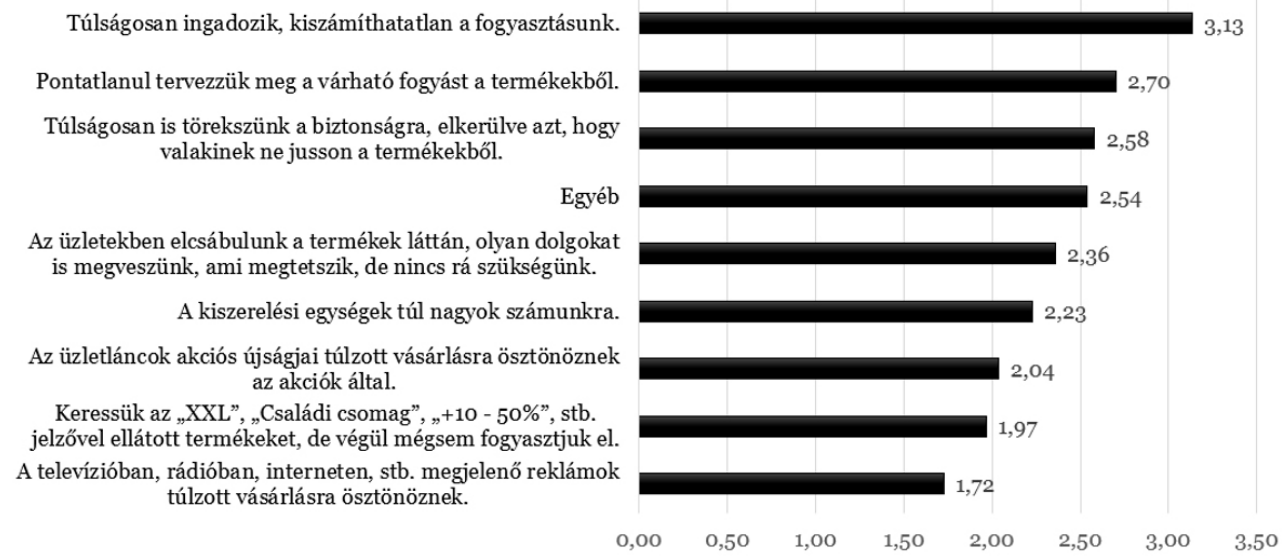

\section{2. ÁBRA}

\section{A felesleg keletkezésének okai (Causes of Surplus Existence)}

FIG. 2

Forrás (Source): Saját kutatás, 2019 (Own research, 2019)

Megjegyzés (Notes): Causes from top to bottom: Our consumption fluctuates too much, unpredictable (3.13), We plan the consumption inaccurately (2.70), We strive for security too much avoiding getting someone out of the products (2.58), Other (2.54), We are inveigled in the shops, we buy products that we like, but we don't need it ((2.36), Packaging units are too big for us (2.23), Promotional newspapers encourage excessive shopping (2.04), Look for "XXL", "Family Package", "+10-50\%", etc. but we do not consume it (1.97), Television, radio, internet, etc. advertisements encourage excessive purchases (1.72). 
Az élelmiszerpazarlás okaiként leírt állítások között egyaránt találunk belső („kiszámíthatatlan a keresletünk”, „pontatlanul tervezzük meg a fogyasztást”, „törekszünk a biztonságra”) és külső („elcsábulunk az üzletekben”, a „kiszerelési egységek túl nagyok”, „az akciós újság hatására vásárolunk”, „keressük a promóciós csomagolást”, „médiában megjelenő reklámok hatására vásárolunk túlzottan”) kiváltó okokat is. Az átlagos értékeket vizsgálva azt tapasztalhatjuk, hogy a belső okok jellemzően magasabb átlagos egyetértési értéket mutatnak fel, vagyis a pazarlás belső okai a dominánsabbak a megkérdezettek szerint. Azt azonban mindenképpen szükséges megjegyezni, hogy sem a belső, sem a külső okokkal szemben nem tapasztalható magas egyetértési szint, hiszen a legmagasabb átlagos érté is 3,13-os értéket vesz fel a fenti, 2. ábrán. A válaszokat vizsgálva úgy tűnik, mintha a fogyasztó kissé ártatlanul szemlélné az élelmiszerek romlását, egyfajta külső szereplőként, amiben neki alig szerepe. Egyfajta sajátos szemléletre engednek a számok következtetni, miszerint a fogyasztó olvasatában „az rendben van, hogy többet vettem a kelleténél, de a hibás az élelmiszer, mert az gyorsan és váratlanul romlott meg”. A romlás jelensége megtörténik, a fogyasztó olvasatában alig-alig tehet róla a válaszok alapján; vagyis egyfajta passzív tagadással kombinált önvédelmi mechanizmusnak lehetünk tanúi. Az „egyéb okként” megjelölt válaszok is erre engednek következtetni. A válaszok között többször is megjelennek a „az élelmiszer gyorsan megromlik”, „hamarabb lejár a szavatossága, minthogy megennénk”, „túl nagy a választék otthon” okok. Kutatásomban mértem azt is, hogy a fogyasztók saját magukat teszik-e inkább felelőssé a felesleg képződéséért vagy az üzletláncok marketingaktivitását. A fogyasztók attitűdjét egy 5 fokozatú szemantikus differenciál skálával mértem, ahol az 1-es érték a saját felelősséget, míg az 5-ös érték az üzletláncok marketingaktivitásának felelősségét hangsúlyozta. Az átlagos 2,6-es érték alapján kijelenthető, hogy a fogyasztók inkább magukat teszik felelőssé a felesleg képződéséért az üzletláncok marketingaktivitásával szemben, de közepes érték közelsége jelzi, hogy az üzletláncok szerepét sem sorolják igazán háttérbe.

Fontos kérdés annak vizsgálata is, hogy mi történik a felesleggel. A leggyakrabban megjelölt válaszlehetőség $(60,1 \%)$, hogy a megmaradt élelmiszert haszonállat takarmányozásra hasznosítják a családok. A megkérdezettek 29,8\%-a jelölte meg, hogy a felesleget a kukába dobják, azt semmilyen formában sem próbálják, tudják hasznosítani. Az egyéb formában történő hasznosítás (pl. zsemlemorzsát készítünk) 7,6\%-os aránnyal jelent meg a felsorolásban. Kiemelendő, hogy az „elajándékozzuk a minőségmegőrzési határidő lejárta előtt” opció a hazai fogyasztók számára kevéssé népszerü, csupán a megkérdezettek 1,7\%-a jelölte meg ezt a válaszlehetőséget a felesleg felhasználási módjaként. Semmiképpen sem szabad arról a módszertani sajátosságból adódó hátrányról megfeledkeznünk, hogy a megkérdezettek a vélelmezett helyes válaszoknak megfelelöen „szépíthetik” válaszaikat (például nagyobb arányban jelöli meg a takarmányozást vagy ajándékozást, mert ezt érzi helyesnek), elrejtve a társadalmilag elítélendő magatartás (például élelmiszert dob a kukába) valódi nagyságát. A már korábban említett Magyar Élelmiszerbank Egyesület számára komoly lehetőségeket rejthet magában a háztartások erőteljesebb bevonása a rendszerbe az üzletláncok, pl. Aldi, Auchan, Metro és Tesco mellett. Ennek megvalósítása nehéz feladat, hiszen a Skinner-i értelemben vett, operáns kondicionáláson alapuló magatartásformálás egy rendkívül lassú és nehéz folyamat.

\section{KÖVETKEZTETÉSEK ÉS JAVASLATOK - CONCLUSIONS AND RECOMMENDATIONS}

Jelenlegi és korábbi kutatási eredményeim alapján kijelentem, hogy bármennyire is szeretjük azt gondolni magunkról, hogy tudatos fogyasztók vagyunk, ez a kijelentés általánosságban nem igaz, aminek kiváló példája az élelmiszerek felhasználásnak területe. Korábbi kutatási eredményeim (SZỨCS, 2019) alapján egyértelmúvé vált számomra, hogy a fogyasztó rendkívüli módon szeretné hangsúlyozni tudatosságát. Ezek a kutatások arra is rávilágítottak, hogy a vélt tudatosságot alig képesek néhányan valódi tudással is alátámasztani. Jelen 
kutatás felhívta a figyelmet arra a jelenségre is, hogy a cselekvés, a konatív komponens ennél is gyengébb szintü, még egy olyan területen is, mint az élelmiszerek hatékony felhasználására való törekvés. Amennyiben elfogadjuk azt az alapfeltevést, hogy a tudatos fogyasztáshoz igenis az ismeretek és a cselekvés összhangja szükséges, akkor a hazai fogyasztói tudatosságot, beleértve az élelmiszerek felhasználását is, egy jéghegyhez tudnám hasonlítani. Egy nagyon szúk szegmens a víz felett van, míg a többiek a víz alatt, láthatatlanul, elsüllyedve. A kutatás tárgyától változóan az arány is nagyjából azonos: $10-20 \%$ a víz felett, $80-90 \%$ a víz alatt található. A fenti gondolatkört az alábbi, általam készített 3. ábrával szemléltetem. Szükséges megjegyezni, hogy jelen ábrának nem célja egyfajta hatástényezóket szintetizáló matematikai modell megalkotása, az ábrán szereplő tényezők számszerüsítése (az más, az egyes tényezóket külön vizsgáló publikációkban megvalósult). Az ábra célja az egyszerü szemléltetés, a vizuális ábrázolás.

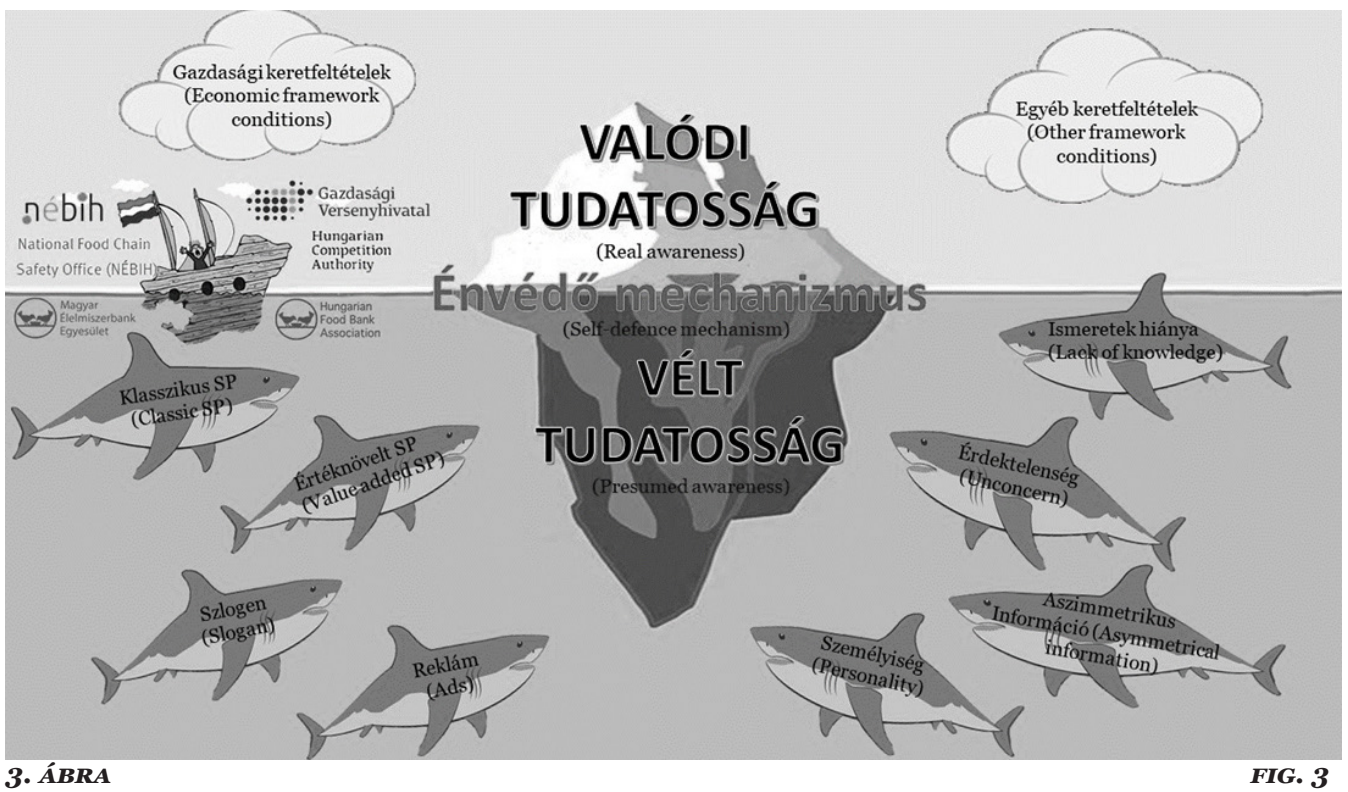

3. ÁBRA

A jéghegy-effektus a fogyasztói tudatossággal összefüggésben

(The Iceberg-Effect in the Context of Consumer Awareness)

Forrás (Source): Saját kutatás, 2019 (Own research, 2019)

A fogyasztó szocializációja egyfajta fekete-dobozt alkot, mely többek között a fogyasztó személyiségjegyeinek, énvédő mechanizmusának, érdeklődési körének, életkörülményeinek, iskolázottságának, életkorának, családi életciklusának, a referencia csoportok hatásának következménye, mely a fogyasztóvá válásunk hajnalán kialakul és nagyon lassan formálódik. Jól látható, hogy az élelmiszerek felhasználása tekintetében a jövedelemnek kiemelt szerepe van a tudatos felhasználás alakulásában. A fogyasztói szocializációban egyrészt ott vannak a makrokörnyezeti elemek (társadalmi, gazdasági, politikai, jogi, kulturális, technológiai), illetve természetesen a mikrokörnyezet befolyásoló hatása is érvényesül. Ezen hatások, nevezzük őket összességében keretfeltételeknek, koherens egészet alkotva alakítják és formálják a fogyasztó magatartását, csiszolva annak fekete-dobozát. Ez a fekete-doboz alkotja és magyarázza magát a fogyasztót, mely számunkra racionális és irracionális döntésekben ölt testet, leírja annak tudatossági szintjét. Ez a legutolsó lépcsőben, az élelmiszerek tudatos felhasználásában ölt testet, ami leginkább kézzelfogható módon az üzletekben figyelhe- 
tő meg, akkor, amikor a fogyasztó nem tesz a kosarába olyan mennyiségben élelmiszert, aminek pazarlás lesz a vége. A fogyasztó magatartására a marketing ingerek befolyásoló hatást fejtenek ki, mely hatás befogadásának, így a befolyásolhatóság mértékének alakulása erőteljesen függ a fogyasztó fekete-dobozától. Ennek függvénye az, hogy a fogyasztó menynyire fogékony az egyébként kicsiszolt marketing eszköztár befogadására, a kis összegú és értéknövelt sales promotion aktivitásokra, a kommunikációs eszköztár alapvetőnek tekinthető üzenetére, a szlogenekre, stb. Az élelmiszerek piacán is találkozunk ilyen egyszerü ingerekkel, úgymint az „XXL” jelző, a „Családi csomag”, a „+50\% ajándék” feliratok. Ezek az ingerek a fenti szemléltető ábrán cápaként lesnek a fogyasztóra, hajlandóság esetén lecsapnak rá. Aki a víz alatt található, rájuk könnyen vadászhatnak, a víz felett lévőkre kevésbé. A fogyasztói ismeretek megszerzésének képessége és készsége, a hajlandóság szintén ettől a zárt fogyasztói rendszertől függ alapvetően. Ez természetesen a fogyasztók kognitív képességeit fejlesztő programokkal (a fogyasztói tudatosságot formáló és ismeretterjesztő aktivitások bármilyen formája) alakítható, bővíthető. Ahogyan a jéghegy, úgy a fekete-doboz is formálódik, változtatja alakját és méretét. Ezek a változások azonban nem egyik pillanatról a másikra következnek be. A fogyasztótól meglátásom szerint igenis elvárható az, hogy ezekre a hatásokra nyitott legyen, ne érvényesüljön a Vidra-effektus, vagyis bármilyen hasznos információ megszerzésétől a fogyasztó ne zárkózzon el („ne zárja be a fülét”). A fogyasztóvédelem egyfajta játékteret biztosít az ott lévő szereplők számára, meghatározva a legfontosabb játékszabályokat, de - mint minden játékban - alapvetően a játék tisztaságát nem pusztán a szabályok generálják. A játék tisztasága, a fogyasztói jogok elfogadható szintű ismerete vagy a pazarlás mennyiségének csökkentése hosszútávon az összes piaci szereplő érdeke, legyen szó a food vagy non-food termékek piacáról (lásd müszaki cikkek egyre rövidülő termékélet-görbéje, a szervizelhetőség lehetőségének csökkenése, stb.) A Gazdasági Versenyhivatal vagy a fogyasztóvédelem bármely intézménye, az élelmiszerpazarlással összefüggésben a Magyar Élelmiszerbank Egyesület egyfajta mentő- hajóként írható le ezen a tengeren, akik mentőövet dobhatnak a fogyasztó számára szükség esetén. Azt azonban mindenképpen látni kell, hogy kizárólagosan tólük várni a segítséget komoly hiba lenne. Ahogyan a 3. ábra is szemlélteti, az ő hajójuk is hiányos, egyszerűen nem tudnak mindenkit megmenteni, nem lehetnek mindenhol ott, nem fér fel mindenki a mentőhajóra. Nem azért mert bármi gond lenne a hajójukkal vagy a rendszerükkel, hanem azért mert a piac (az óceán) hatalmas. A fogyasztói magatartás formálása nem egyszerü feladat, különösen nem az élelmiszerek felhasználásának területén. Egyrészt egy nagyon erős, hozott minta is megfigyelhető a háztartásokban („kenyérnek márpedig lennie kell itthon”), másrészt a fogyasztók bevonása sem egyszerű a különböző mentőprogramokba. Ehhez a szemléletváltáshoz egyrészt idő (pl: iskolai programok, tájékoztatók egészen kisgyermek korban), másrészt új és újszerű kommunikációs eszközök alkalmazása lehet hatékony eszköz (pl: ismert személyek megnyerése a közösségi média felületén, akik népszerüsítik az élelmiszerek mentését). A helyzet javítását célzó kezdeményezések elindultak, a NÉBIH példának okán elindította az élelmiszerpazarlás-megelőző kampányát „Maradék nélkül” néven, amelynek 2018-ban elindult az iskolai programja is.

\section{6. ÖSSZEFOGLALÁs - SUMMARY}

Összefoglalásként megállapítható, hogy napjainkban egyre inkább kiemelt figyelem övezi az élelmiszerek hatékony felhasználására való törekvést. Ez a törekvés mára nem csupán makro szinten valósul meg, hanem egyre inkább megjelenik a háztartások gondolatkörében is. A pazarlás nem csupán a tôlünk kedvezőbb gazdasági mutatószámokkal rendelkező országok problémája, hanem bizony „mi” is vagyunk azok az „ok”, akik pazarolják az élelmiszert. Egy olyan országban, mint hazánk, ahol az EU átlagához viszonyított jövedelemszint alacsony, kiemelt figyelmet kell, hogy jelentsen az élelmiszerek hatékony felhasználása. Ennek megvalósulásáért, ellentétben nagyon sok minden mással, maga a háztartás, az egyén tehet a legtöbbet. A kutatás rámutatott arra, hogy az élelmiszer pazarlás összefügg a fogyasztó 
bevallott jövedelmi szintjével. Az átlagostól alacsonyabb bevallott jövedelemszinttel rendelkezók esetében azt tapasztalhattuk, hogy a pazarlás becsült mértéke a több termék esetében is csökkent az átlagoshoz képest. Az átlagostól magasabb bevallott jövedelemszinttel rendelkezók esetén a becsült pazarlás mértéke emelkedik több termékkategóriában is. A jövedelemszint emelkedésével a tudatos felhasználás csökkent, a pazarlás mértéke emelkedő tendenciát mutatott. A kérdés természetesen nem ennyire egyszerü, hiszen a gazdasági keretfeltételek, a játékszabályok megvalósítása komoly nemzetgazdasági vagy ezen is túlmutató, szupranacionális kérdés lehet. A tudatosság szintjére eredményeim alapján a család jövedelme komoly hatást fejt ki, a jövedelmi szint emelkedésével a tudatossági fegyelem csökken. Ez az eredmény összefügg a szakirodalom makrogazdasági adataival.

\section{IRODALOMJEGYZÉK - REFERENCES}

BIOIS: Preparatory Study on Food Waste Across EU 27. 2011. http://ec.europa.eu/ environment/eussd/pdf/bio_foodwaste report.pdf. (Letöltés dátuma: 2019.03.10.)

Deák, F.:Élelmiszerpazarlás, Földmüvelésügyi Minisztérium, Élelmiszerlánc-felügyeleti Főosztály, 2017. 25. https://www. hungalimentaria.hu/Portals/o/2017_ eloadasok/2-1\%2oDeak\%2oFerenc\%20 - \% 20 Elelmiszerpazarlas \% 202017 04-27\%20B.pdf (Letöltés dátuma: 2019.03.10.)

EUROSTAT: Material and Social Deprivation. 2017. https://ec.europa.eu/eurostat/ web/products-eurostat-news/-/DDN20171212-1?inheritRedirect=true\&redir ect $=\% 2$ Feurostat\%2F (Letöltés dátuma: 2019.03.10.)

FAO: The State of Food Security and Nutrition in the World, Building Climate Resilience for Food Security and Nutrition. 2018. 202., 16. https://http://www.fao.org/3/ I9553EN/i9553en.pdf (Letöltés dátuma: 2019.03.10.)
F. Szabó, E. (2017): Pazarol a világ, és én segítek neki, Pallas Athéné Geopolitikai Alapítvány, https://vs.hu/mega/pazarola-vilag/ (Letöltés dátuma: 2019.03.10.)

Hubert, K. - Szúcs, I.: A hazai háztartási élelmiszer-hulladékba kerülő kenyér egyes gazdasági, társadalmi és ökológiai hatásai. Gazdálkodás. 2017. 61 (1) 54-72.

KSH: Európai lakossági egészségfelmérés, 2014. Statisztikai Tükör. 2015. 29. 9. https://www.ksh.hu/docs/hun/xftp/ stattukor/elef14.pdf (Letöltés dátuma: 2019.03.10.)

KSH: A háztartások fogyasztása, 2018. I. félév (előzetes adatok alapján), Statisztikai Tükör. 2018a. 3. http://www.ksh.hu/ docs/hun/xftp/stattukor/haztfogy/ haztfogy1806.pdf (Letöltés dátuma: 2019.03.10.)

KSH: A háztartások életszínvonala, 2017. 2018b. 33., https://www.ksh.hu/docs/ hun/xftp/idoszaki / hazteletszinv/ hazteletszinv17.pdf, (Letöltés dátuma: 2019. 03.10.)

KSH: Gyorstájékoztató, Keresetek, 2018. január-december, 329900 forint volt a bruttó átlagkereset. 2019. http://www. ksh.hu/docs/hun/xftp/gyor/ker/ker1812. html (Letöltés dátuma: 2019.03.10.)

Luhby, T.: The Top 26 Billionaires Own $\$ 1.4$ Trillion - As Much as 3.8 Billion Other People, CNN Business. 2019. https:// edition.cnn.com/2019/o1/20/business/ oxfam-billionaires-davos/index.html (Letöltés dátuma: 2019.03.10.)

Naeem, A. - Brzozowski, M - Crossley, T. F.: Measurement Errors in Recall Food Consumption Data. The Institute For Fiscal Studies, 2006. WPo6/21, 41. https://www.ifs.org.uk/wps/wpo621.pdf (Letöltés dátuma: 2019.05.06.)

NÉBIH: Maradék nélkül elnevezésű kampány nyitókonferenciája. 2016. http://maradeknelkul.hu/2016/11/25/ hivatalosan-is-kezdetet-vette-a-nebihmaradek-nelkul-programja/ (Letöltés dátuma: 2019.05.06.) 
OECD: Obesity Update. 2017. 16. https:// www.oecd.org/els/health-systems / Obesity-Update-2017.pdf pdf (Letöltés dátuma: 2019.03.10.)

Stenmarck, Å. - Jensen, C. - Quested, T. - Moates, G.: Estimates of European food waste levels. FUSIONS Reducing food waste through social innovation. IVL Swedish Environmental Research Institute, Stockholm 31 March 2016., 80. http:// www.eu-fusions.org/phocadownload/ Publications / Estimates \% 20 of\% 20 European\%2ofood\%20waste\%2olevels. pdf (Letöltés dátuma: 2019. 03. 10.)

Szabó-Bódi, B. - Kasza, Gy. - Szakos, D.: Assessment of Household Food Waste in Hungary. British Food Journal. 2018. 120 (3) https://doi.org/ 10.1108/BFJ-042017-0255

Szabó-Bódi, B.: Az élelmiszerhulladékok szerepe a környezeti terhelésben Társadalmi megítélés és szerepvállalás, Doktori értekezés, Szent István Egyetem, Tájépítészeti és Tájökológiai Doktori Iskola, 2018.
Szúcs, R. S.: A fogyasztói tudatosság marketing és fogyasztóvédelmi szempontú vizsgálata: Tézisszerű bevezetővel ellátott cikkgyưjtemény a habilitáció elnyerésére, Debreceni Egyetem, Ihrig Károly Gazdálkodás- és Szervezéstudományok Doktori Iskola, Disszertáció benyújtásának éve: 2018, Védés éve: 2018. Megjelenés/ Fokozatszerzés éve: 2019.

WHO: Obesity and Overweight. 2018. URL: https://www.who.int/news-room/factsheets/detail/obesity-and-overweight (Letöltés dátuma: 2019.03.10.)

World Resource Institute: Reducing Food Loss and Waste. 2013. http://pdf.wri. org/reducing_food_loss_and_waste.pdf (Letöltés dátuma: 2019.05.06.)

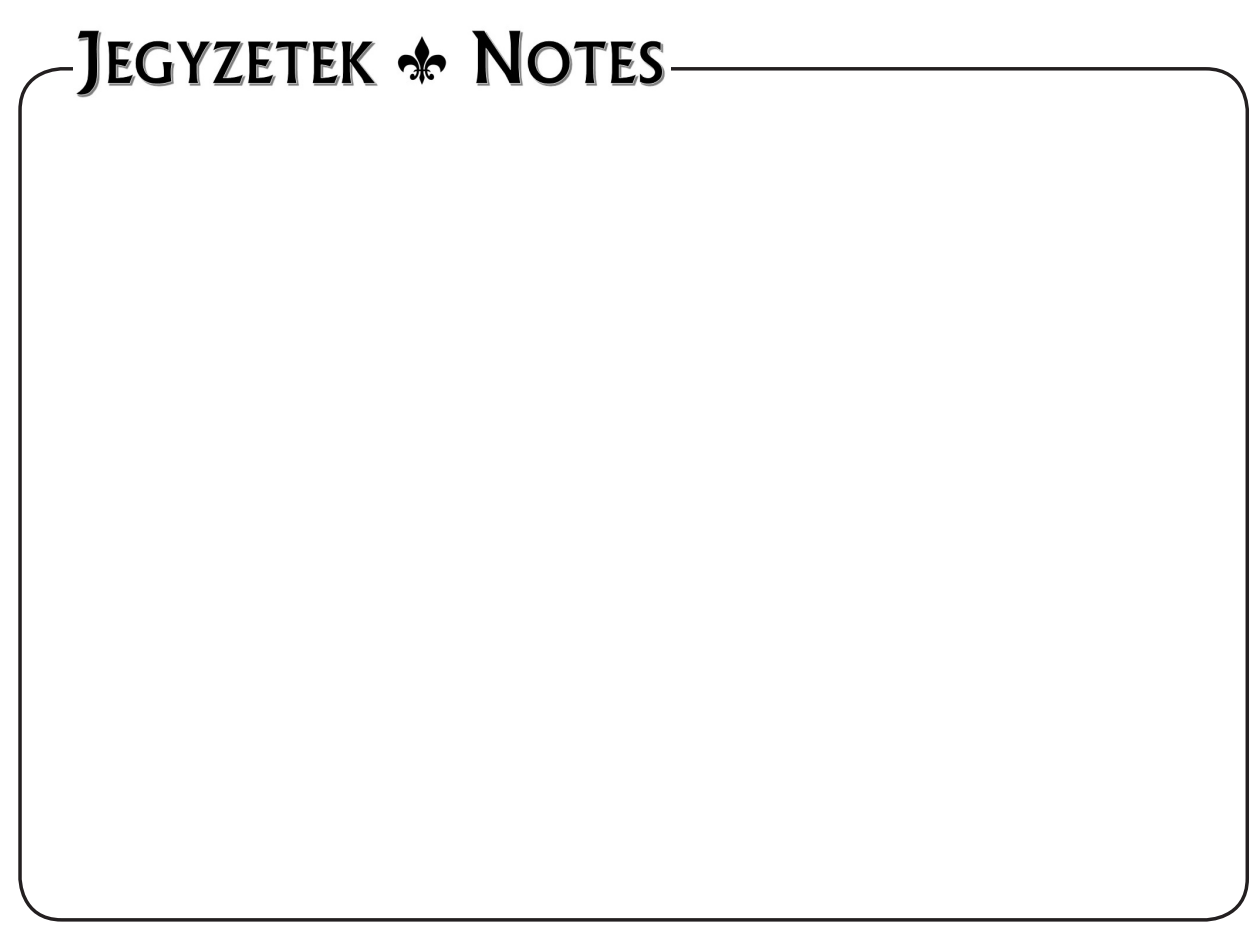

